\title{
FAKTOR PENENTU STRUKTUR MODAL : BUKTI EMPIRIS PADA INDEKS IDX30 BURSA EFEK INDONESIA
}

\author{
*Nur Fitriyanto ${ }^{1}$ \\ Slamet Haryono ${ }^{2}$ \\ (UIN Sunan Kalijaga Yogyakarta )
}

\section{ARTICLE INFO}

Keywords:

leverage, regresi data panel, Moderated

Regression Analysis (MRA)

\section{ABSTRACT}

This study aims to examine the influence of determinants of capital structure, such as business risk, dividend payout ratio, growth opportunities, sharia compliance, non-debt tax shield, profitability and tangibility toward corporate leverage by being moderated by the size of the company. The population of this study is companies that have listed on IDX30 index, with a purposive sampling method obtained by a sample of 15 companies. This study found that profitability and non-debt tax shiled had significant negative effect, business risk and firm size had significant positive effect and dividend payout ratios and sharia compliance had a significant negative effect, while future growth opportunities and firm tangibility did not significantly influence leverage company.

\begin{abstract}
ABSTRAK
Penelitian ini bertujuan untuk menguji pengaruh faktorfaktor penentu struktur modal, seperti risiko bisnis, dividend payout ratio, peluang pertumbuhan, kepatuhan syariah, perisai pajak non hutang, profitabilitas dan tangibilitas terhadap leverage perusahaan dengan dimoderasi oleh ukuran perushaan. Populasi dari penelitian ini adalah perusahaan yang pernah masuk kriteria indeks IDX30, dengan metode purposive sampling didapatkan sampel penelitian sejumlah 15 perusahaan. Penelitian ini berhasil menemukan bahwa profitabilitas dan non-debt tax shiled memiliki pengaruh negatif signifikan kuat, risiko bisnis dan ukuran perusahaan berpengaruh positif signifikan dan dividend payout rasio dan kepatuhan syariah berpengaruh negatif signifikan, sedangkan peluang pertumbuhan dimasa depan dan tangibilitas perusahaan tidak berpengaruh signifikan terhadap leverage perusahaan.
\end{abstract}

How to Cite:

Slamet Haryano. (2020). Faktor Penentu Struktur Modal : Bukti Empiris pada Indeks IDX30 di Bursa Efek Indonesia, $15(1), \quad 85-106 \quad$ https://doi.org/10.21009/wahanaakuntansi/15.1.07 


\section{PENDAHULUAN}

Keputusan struktur modal sangat penting akan mempengaruhi langsung terhadap tingkat kinerja perusahaan, nilai perusahaan dan akhirnya berimbas pada kesejahteraan pemegang saham. Struktur modal yang tepat mengarahkan perusahaan untuk mencapai kinerja yang lebih baik dan memastikan keberlanjutan dalam operasinya (Murray Z. Frank Vidhan K. Goyal, 2009, Rathiranee Yogendrarajah, 2015, R. Angayarkanni, 2018).

Keuangan Islam memiliki karakteristik berbeda karena dalam mengoperasikan kegiatannya termasuk pada industri pasar modal dan kebijakan manajemen terkait sumber pendanaan atau permodalan. Dinamika kebijakan manajemen terkait siklus leverage di perusahaan masih menjadi pertanyaan yang menarik. Perusahaan ada yang menargetkan tingkat rasio leverage yang berkembang sejalan dengan siklus industri dan perusahaan yang juga mengalami kemampuan finansial terbatas (Halling dkk, 2016)

Perkembangan rasio hutang perusahaanperusahaan di Amerika Serikat yang terjadi di semua industri yang tidak diatur secara ketat dan untuk semua ukuran perusahaan terus meningkatkan dari sebelum 1945 sebesar $11 \%$ dan pada 1970 sebesar $35 \%$, mencapai $47 \%$ pada awal 1990-an (John R. Graham, et al., 2015). Struktur modal merupakan topik yang selalu menarik untuk diteliti. Struktur modal berperan dalam peningkatkan eksistensi bisnis sebuah perusahaan, apabila diambil dengan kebijakan yang tepat oleh manajemen perusahaan. Ada beberapa pilihan dalam penggunaan sumber dana dalam proses invasi bisnis perusahaan. Baik itu sumber dana berasal dari internal maupun eksternal. Setiap kebijakan yang diambil tentu sepasang dengan risi- ko yang akan dihadapi sebuah perusahaan. Kesalahan fatal dalam pemilihan sumber dana maupun proporsinya akan berakibat membahayakan perusahaan.

Penelitian-penelitian mengenai struktur modal banyak menarik para peneliti. Dari berbagai penelitian yang sudah dilakukan seperti Haron (2014), Rajan dan Zingales (1995), Malinic (2013), Nadeem dan Wang (2011), Esperenca et al (2003) dan masih banyak lagi, masih memberikan hasil yang beragam. Tentu hal ini masih menjadi celah penelitian yang bisa digunakan untuk referensi lebih banyak lagi perusahaan dalam menentukan stuktur modal yang ideal.

M'ng et al (2017) sepakat dalam hasil penelitian dengan Esperenca et al (2003) dan Rajan dan Zingales (1995), bahwa tangibilitas perusahaan memiliki pengaruh yang positif terhadap struktur modal perusahaan. Semakin tinggi nilai tangibilitas perusahaan, maka tingkat hutang perusahaan akan tinggi, karena perusahaan semakin percaya diri dengan aset yang dimiliki. Hal ini bertentangan dengan penelitian yang dilakukan oleh Booth et al (2001), Nadeem dan Wang (2011) dan Malinic (2013), mereka menyatakan tangibilitas yang tinggi akan membuat tingkat hutang semakin rendah, atau dengan kata lain tangibilitas berpengaruh negatif terhadap struktur modal (tingkat hutang). Menurut Booth et al, hal itu merupakan bentuk subtitusi jangka panjang untuk hutang jangka pendek yang kurang dari satu tahun. Penelitian yang dilakukan oleh Deesomsak et al. (2004) dan Wald (1999), mengatakan bahwa perusahaan dapat mengganti perisai pajak dari hutang mereka dengan manfaat pajak dari depresiasi dan kredit pajak investasi. Penelitian keuangan 
Islam berkembang pesat, penelitian ini memasukkan unsur penyaringan efek syariah sebagai syarat kajian Ekonomi Islam. Kajian ini juga menggunakan data sampel perusahaan yang patuh terhadap aturan syariah masih terbatas. Menurut Ahmed (2009), perusahaan syariah memiliki aturan-aturan yang membatasi tingkat hutang yang di proporsikan perusahaan, sedangkan perusahaan non syariah tidak memiliki batasan tersebut. Penelitian ini akan menambahkan faktor kepatuhan syariah sebagai variabel yang mewakili apakah label syariah pada perusahaan -perusahaan syariah cukup efektif dalam memilih strukut modal mereka. Alnoria dan Alqahtani (2019) berhasil menunjukkan bahwa kepatuhan syariah berperan penting pada dalam penentuan struktur modal perusahaan.

Dewan Syariah Nasional - Majelis Ulama Indonesia (DSN-MUI), yang memiliki otoritas mengatur keuangan Islam di Indonesia terkait kepatuhan syariahnya sudah mengeluarkan fatwa yang membatasi pilihan kebijakan terkait pendanaan dengan diterbitkannya Fatwa Dewan Syari'ah Nasional NO: 40/DSN-MUI/X/2003 Tentang Pasar Modal Dan Pedoman Umum Penerapan Prinsip Syariah Di Bidang Pasar Modal.

Namun, penelitian Hermanto (2018) menunjukkan bahwa Fatwa DSN-MUI belum mampu mengatur kegiatan transaksi keuangan syariah untuk memenuhi kebutuhan transaksi keuangan modern. Banyak transaksi yang belum diatur dalam Fatwa DSN-MU tetapi sudah diatur dalam peraturan yang dikeluarkan oleh Badan Pengawas Pasar Modal dan Lembaga Keuangan yang saat in menjadi Otoritas Jasa Keuangan (OJK) seperti tentang produk turunan keuangan
Syariah. DSN MUI juga tidak dapat memastikan industri keuangan Islam di Indonesia sudah mencapai kepatuhan Syariah.

\section{TELAAH LITERATUR DAN PENGEM- BANGAN HIPOTESIS}

\section{Teori Modigliani dan Miller}

Teori yang telah lama menjadi pelopor penelitian struktur modal adalah toeri yang dikemukakan Modigliani dan Miller. Penelitian mengenai struktur modal perusahaan telah dimulai oleh Modigliani dan Miller sejak tahun 1958. Mereka meneliti strukutr modal dan hubungannya dengan nilai perusahaan. Modigliani dan Miller (1958) menyatakan bahwa pada pasar yang efisien (dengan tidak adanya pajak, biaya keagenan dan kebangkrutan serta asimteri informasi) nilai dari perusahaan tidaklah dipengaruhi dari hasil penentuan struktur modal perusahaan tersebut. Sedangkan pembiayaan modal perusahaan sepenuhnya bergantung pada risiki bisnis yang dimilikinya. Modigliani dan Miller (1958) telah memulai penelitian tentang struktur modal dan hubungannya dengan nilai perusahaan. Pada kondisi pasar yang efisien (tidak ada pajak, biaya keagenan dan kebangkrutan, asimetri informasi), nilai pasar perusahaan tidak dipengaruhi pada pilihan struktur modalnya sedangkan biaya modal perusahaan sepenuhnya tergantung pada risiko bisnis.Mereka beranggapan bahwa strukut modal dan keputusan pemilihan pembiayaan perusahaan dianggap tidak relevan dalam meningkatkan nilai pemegang saham. Maka dari itu, mereka beranggapan bahwa tidaka da struktur modal yang optimal. Teori yang daijukan ini mengundang banyak kritikan, karena asum-asumsi yang diajukan di- 
anggap para pengkritik tidak masuk akal seperti (tanpa pajak, tidak ada biaya keagenan dan kebangkrutan serta asimteri informasi).

\section{Teori Pecking Order}

Myers dan Majluf pada tahun 1984 memperluas sebuah teori yang telah diperkenalkan oleh Donaldson pada tahun 1961. Dalam teori ini dinyatakan bahwa manajer memiliki lebih banyak informasi tentang nilai sebenarnya dari perusahaan dan risiko risiko dibandingkan dengan investor luar. Menurut Myers (1984), perusahaan membiayai kegiatan mereka dengan pendapatannya jika memungkinkan. Namun, jika laba ditahan tidak memadai, maka hutang menjadi pilihan selanjutnya untuk digunakan. Hanya secara kasuistik yang begitu ekstrem perusahaan akan menggunakan opsi terkahir yaitu, menerbitkan ekuitas baru. Dengan demikian, urutan sumber pendanaan yang digunakan adalah sumber dana internal dari laba, sekuritas jangka pendek, utang, saham preferen dan saham biasa terakhir. Teori pecking order memprediksi bahwa penerbitan ekuitas (saham biasa) adalah sumber alternatif terakhir pendanaan sebuah perusahaan.

\section{Teori Trade Off}

Teori trade-off muncul berdasarkan penelitian tentang pajak yang dilakuakn oleh Modigliani dan Miller pada tahun 1963 dan biaya kebangkrutan dan biaya kesulitan keuangan oleh Warner pada tahun 1977 serta literatur agensi yang dikemukakan oleh Jensen dan Meckling pada tahun 1976. Teori trade off menyatakan bahwa perusahaan memiliki struktur modal optimal ketika berhasil menyimbangkan antara keuntungan pajak dari pembiayaan hutang (yaitu perisai pajak hutang), biaya kesulitan keuangan dan manfaat agen dan biaya utang.

Menurut Myers (1984), perusahaan yang mengikuti teori tradeoff menetapkan target rasio hutang terhadap nilai dan kemudian secara bertahap bergerak menuju target. Targetnya adalah ditentukan dengan menyeimbangkan perisai pajak utang terhadap biaya kebangkrutan. Hal ini sependapat dengan Scott (1977), yang menyatakan bahwa perusahaan masih diperbolehkan mengalokasikan hutang namun ada batasan ketika cost of bankcrupty sudah setara dengan manfaat dari tax savings, maka porsi hutang harus dihentikan.

\section{Teori Agensi}

Menurut Jensen dan Meckling (1976), struktur modal yang optimal diperoleh dengan men trade-off kan biaya agensi dari hutang terhadap manfaat hutang. Jensen dan Meckling merupakan orang yang pertama kali mengidentifikasi perselisihan antara pemegang saham dan manajer karena kepemilikan manajemen kurang dari $100 \%$ dari ekuitas. Hal ini akan menghasilkan pengurangan jumlah uang tunai yang tidak digunakan yang tersedia untuk manajer (Jensen, 1986; Stulz, 1990). Sehingga pada akhirnya akan menguntungkan pembiayaan melalui utang.

Teori agensi telah menunjukkan hubungan positif antara leverage dan nilai perusahaan. Leverage diharapkan berkorelasi negatif dengan cakupan terestrial, pertumbuhan peluang, dan kemungkinan reorganisasi default. Telah dikatakan bahwa nilai perusahaan dan leverage berhubungan positif karena kedua variabel bergerak bersama dalam menanggapi beberapa faktor eksogen (Hirschleifer \& Thakor, 1989). Teori agensi telah menjelaskan teori struktur modal tetapi tidak menguraikan semua perbedaan dalam 
struktur modal yang diamati dalam praktik (Handoo dan Sharma, 2014).

\section{Seleksi Saham Syariah di Indonesia}

Di Indonesia, dalam hal menyeleksi saham syariah dilakukan oleh Dewan Syariah Nasional (DSN). Metode skrining ini telah mengalami beberapa kali perubahan. Dimulai poada tahun 2001, Dewan Syariah Nasional mematok kriteria bagi saham yang masuk kategori syariah adalah perusahaan tersebut bergerak atau beroperasi pada bidang yang tidak bertentangan dengan prinsip syariah untuk bisa masuk ke kelompok indeks JII (Jakarta Islamic Index). Disusul pada tahun 2007, sejak dibentuknya Daftar Efek Syariah (DES), DSN mulai menggunakan kriteria rasio keuangan, rasio keuangan yang digunakan adalah debt to equity ratio atau rasio hutang terhadap ekuitas. Besaran rasio hutang terhadap ekuitas tidak boleh melibih $82 \%$. Pada tahun 2012, kriteria yang digunkan mengalami perubahan lagi, kriteria itu direvisi dengan mengganti rasio hutang terhadap ekuitas menjadi rasio hutang terhadap aset perusahaan, aturan tersebut berlaku hingga saat ini. Tambahan kriteria yang lainyang wajib dipenuhi oleh perusahaan untuk masuk kelompok saham syariah adalah perusahaan tidak boleh beroperasi pada kegiatan yang bertentangan dengan syariat Islam serta pendapatan yang dihasilkan dari kegiatan tidak halal tiodak boleh melebihi angka 10\%.

\section{Penelitian Terdahulu}

Penelitian yang telah dilakukan oleh Akinsomi et al. (2015) dan Naz et al. (2017) menunjukkan bahwa ada perbedaan yang signifikan ketika struktur modal ditentukan antara perusahaan yang patuh terhadap syariah dengan perusahaan yang tidak mengikuti aturan Syariah, hal ini dikarenakan perbedaan batasan-batasan yang diberlakukan. Alnoria dan Alqahtani (2019) mengemukakan bahwa kepatuhan syariah merupakan peranan cukup penting bagi perusahaan dalam menentukan kebijakan struktur modal. Penelitiannya menyimpulkan bahwa, perusahaan yang patuh aturan syariah memiliki tingkat hutang yang lebih rendah dibandingkan dengan perusahaan yang tidak patuh syariah, struktur modal ini diukur dengan proksi book dan market. Penelitian Farooq and Tbeur (2013) juga membuktikan bahwa perusahan syariah memiliki tingkat leverage perusahaan yang lebih rendah daripada perusahaan non syariah.

Malinic et al (2013) menemukan hubungan negatif antara likuiditas, profitabilitas dan kesenjangan kas terhadap rasio hutang. Nadeem dan Wang (2011) menunjukkan hasil adanya hubungan yang positif antara ukuran perusahaan dengan rasio hutang pada perusahaan Bursa Efek Pakistan.

Sedangkan Sahudin et al. (2019) memiliki hasil yang seragam dalam penelitiannya terhadap faktor penentu struktur modal. Mereka sama-sama melaporkan bahwa ukuran, profitabilitas dan likuiditas perusahaan yang semakin besar maka mengakibatkan rasio hutang yang semakin mengecil. Guner (2015) juga melaporkan bahwa peluang pertumbuhan memiliki pengaruh negatif terhadap rasio tingkat hutang perusahaan di Borsa Istanbul Turki, sedangkan Sahudin et al (2019) mengungkapkan tangibilitas dan risiko kebangkrutan berpengaruh negatif dan efisiensi berpengaruh positif terhadap tingkat hutang perusahaan di Malaysia.

M'ng et al. (2017) meneliti pada tiga bursa 
negara yaitu Malaysia, Singapura dan Thailand, hasil temuan mereka variatif antar negara, seperti di Malaysia dan Singapura, variabel profitabilitas berpengaruh negatif signifikan terhadap struktur modal perusahaan, sedangkan di Thailand tidak signifikan. Mereka juga menemukan bahwa tangibilitas memiliki pengaruh positif terhadap dtruktur modal perusahaan, sedangkan di Thailand tidak berpengaruh. Di semua negara, ukuran perusahaan memiliki pengaruh positif sedangkan depresiasi total aset memperlihatkan pengaruh yang negatif terhadap struktur modal perusahaan pada bursa tersebut.

\section{Pengembangan Hipotesis}

\section{Struktur Modal}

Merujuk pada penelitian yang telah dilakukan sebelumnya, seperti Arif dan Mai (2020), Guner (2016), Hossain dan Ali (2012), Nadeem dan Wang (2011), Rajan dan Zingales (1995) telah menggunakan struktur modal diukur dengan menggunakan total debt yang berisi long term debt dan short term debt dibagi dengan total assets.

\section{Business Risk}

Risiko bisnis mengacu pada risiko yang terkait dengan operasi masa depan bisnis. Perusahaan dengan risiko bisnis yang lebih tinggi menghadapi kesulitan biaya keuangan yang lebih tinggi. Secara umum, diharapkan ada hubungan terbalik antara leverage dan risiko bisnis terkait dengan peningkatan risiko kebangkrutan (Burgman 1996; Chen et al. 1997).

Teori trade off juga menyatakan perusahaan yang memiliki utang yang tinggi cenderung memiliki volatilitas atau fluktuasi pendapa- tan yang tinggi. Tingginya volatilitas sejalan dengan semakin meningkatnya business risk perusahaan. Risiko bisnis yang meningkat, akan diikuti oleh cost of fund. Semakin tinggi cost of fund, maka akan memaksa perusahaan menekan penggunaan hutang perusahaan (Dan Dhaliwal, J. Scott Judd, Matthew Serfling, Sarah Shaikh, 2016).

Risiko bisnis berkaitan dengan pertumbuhan dan struktur modal. Jenis usaha yang berisiko tinggi, memiliki pertumbuhan lebih tinggi. Kreditur tidak menyukai menanamkan dananya pada proyek dengan tingkat pertumbuhan rendah (Quratulain Zafar, Winai Wongsurawat \& David Camino, 2019.

Dengan demikian, hipotesis yang diajukan adalah risiko bisnis berpengaruh negatif signifikan terhadap struktur modal. Hipotesis ini didukung oleh penelitian yang dilakukan Scott, 1977; Burgman 1996; Chen et al. 1997; dan Furi dan Saifudin, 2012)

\section{$\mathrm{Ha}_{1}$ : Business risk memiliki pengaruh negatif signifikan terhadap book leverage.}

\section{Dividend Payout Ratio}

Perusahaan dalam menetapkan tingkat pembayaran dividen beberapa faktor kunci yang dipertimbangkan yaitu free cash flow, growth, likuiditas, profitabilitas dan size. Jadi pembayaran dividen kemungkinan akan memainkan peran utama dalam keputusan bauran pendanaan perusahaan (Franc-Da,browskaa et al, 2020). Bhaduris (2002) mengemukakan bahwa dividen adalah sinyal kesehatan keuangan bagi orang luar. 
Sebuah perusahaan dengan aliran dividen yang konstan akan menghadapi informasi yang kurang asimetris ketika memasuki pasar ekuitas. Pembayaran dividen mengurangi jumlah dana internal dan meningkatkan kebutuhan untuk pembiayaan eksternal. Kebijakan dividen memungkinkan pelepasan sumber daya ketika perusahaan tidak memiliki proyek menguntungkan dan menyampaikan informasi tentang harapan masa depan perusahaan ke pasar modal. Ada hubungan positif antara rasio pembayaran dan utang (Frank dan Goyal, 2004).

Dengan demikian, hipotesis yang diajukan adalah Dividend Payout Rasio berpengaruh positif terhadap leverage perusahaan. Studi empiris yang menyatakan ini adalah Frank dan Goyal (2004).

\section{$\mathrm{Ha}_{2}$ : Dividen Payout Ratio memiliki pengaruh positif signifikan terhadap book leverage. \\ Growth Opportunity}

Teori trade off menyatakan bahwa perusahaan yang memiliki aset tidak berwujud berupa peluang pertumbuhan yang tinggi dimasa depan, memiliki kecenderungan untuk melakukan pembiayaan dengan hutang lebih sedikit, karena peluang pertumbuhan tidak dapat menjadi jaminan. Jensen dan Meckling (1976), Myers and Majluf (1984), dan Fama and French (2000) kompak menyimpulkan bahwa perusahaan dengan peluang pertumbuhan masa depan yang tinggi harus menggunakan lebih banyak pembiayaan dari penerbitan saham baru, hal ini karena perusahaan yang memiliki tingkat hutang yang lebih tinggi lebih biasanya melewatkan peluang investasi yang menguntungkan.
Studi yang menyatakan peluang pertumbuhan perusahaan berhubungan negatif dengan struktur modal (Rajan dan Zingales, 1995; De Miguel dan Pindado, 2001; Bevan dan Danbolt, 2001; Buferna et al, 2005; and Akhtar and Oliver, 2009).

\section{Ha $_{3}$ : Growth Opportunity memiliki pengaruh negatif signifikan terhadap book leverage.}

\section{Kepatuhan Syariah}

Arif dan Mai (2020), Alnoria dan Alqahtani (2019), Farooq and Tbeur (2013) dan Akinsomi et al. (2015) sepakat menayatakan bahwa perusahaan yang patuh terhadap atusran syariah, cenderung memiliki tingkat hutang yang rendah. Hal ini disebabkan karena prinsip kehatihatian pada perusahaan syariah dalam melakukan pemilihan pembiayaan yang aman bagi perusahaan, disamping itu ada batasan tertentu dari masing-masing komisi syariah setiap bursa dalam membatasi tingkat hutang maksimal perusahaan.

Penelitian yang dilakukan oleh Arif dan Mai (2020), Alnoria dan Alqahtani (2019), Farooq and Tbeur (2013) dan Akinsomi et al. (2015) menyatakan bahwa kepatuhan syariah berpengaruh signifikan negatif terhadap book leverage.

\section{Ha4: Kepatuhan Syariah memiliki pengaruh negatif signifikan terhadap book leverage. \\ Non-debt tax shield}

Non-debt tax shield atau perisai pajak non hutang merupakan jenis pengeluaran lain yang memiliki kekuatan untuk menghasilkan perlindungan pajak selain dari beban bunga (Hosain dan Ali, 2012). Non-debt Tax Shield adalah variabel kontribusi untuk mengamankan aset perusahaan dan memiliki dengan leverage perusahaan. 
NDTS memiliki pengaruh negatif terhadap leverage karena nilai NDTS tinggi maka perusahaan menikmati manfaat pajak, sehingga mempengaruhi leverage secara negatif (Quratulain Zafar, Winai Wongsurawat \& David Camino (2019).

DeAngelo dan Masulis (1980) dalam penelitiannya mengusulkan untuk mengambil manfaat dari depresiasi dari aset yang dimiliki perusahaan. Perusahaan yang memiliki potensi nilai perisai pajak non hutang (NDTS) lebih tinggi, maka akan mengurangi porsi hutang mereka, sehingga NDTS ini memiliki hubungan yang negatif dengan struktur modal perusahaan. Wald (1999) dan Deesomsak et al. (2004) menyatakan bahwa ada hubungan negatif yang signifikan antara tingkat hutang dan perisai pajak non utang.

Dengan demikian, hipotesis yang diajukan dalam penelitian ini adalah NDTS memiliki pengaruh negative terhadap hutang atau book leverage.

\section{Ha5: Non-debt Tax Shield memiliki pengaruh negatif signifikan terhadap book leverage.}

\section{Profitabilitas}

Terdapat hubungan yang erat antara profitabilitas dan struktur modal. Menurut teori tradeoff, perusahaan yang lebih tinggi profitabilitasnya cenderung memiliki lebih banyak hutang, hal itu akan lebih bermanfaat dalam kaitannya dengan kebijakan pajak (Myers, 2001). Hal ini karena perusahaan dapat memiliki kesempatan yang lebih baik untuk melindungi lebih banyak keuntungan dengan menggunakan pajak dari hutang. Teori pecking order menyatakan bahwa perusahaan lebih disarankan menggunakan dana yang dihasilkan secara internal terlebih dahulu jika memungkinkana dan memilih utang daripada penerbitan saham baru jika diperlukan. Perusahaan yang memiliki laba yang tinggi, cenderung memiliki hutang yang rendah, atau dengan kata lain profitabilitas berpengaruh negatif terhadap tingkat rasio hutang perusahaan. Pepis, Scott and de Jong, Pieter, 2019 menguji menguji dampak kepatuhan syariah terhadap nilai perusahaan secara jangka penjang. Hasilnya yaitu bahwa kepatuhan syariah berpengaruh positif terhadap kinerja keuangan jangka panjang berupa nilai Retrun on Asset (ROA) dan Return on Sales (ROS). Kepatuhan terhadap Syariah secara kuantitatif merupakan strategi manajerial jangka panjang dan berimplikasi positif terhadap nilai perusahaan.

Perusahaan yang teregulasi memiliki kombinasi rasio leverage ekonomi yang relatif stabil selama abad ke-20, (John R. Graham, et al., 2015). Hussain et al., (2018) menguji pengaruh kepatuhan syariah terhadap kecepatan penyesuaian terhadap target struktur jatuh tempo utang. Hasilnya yaitu perusahaan-perusahaan termasuk memenuhi kepatuhan Syariah cenderung menyesuaikan dengan target jatuh tempo utang lebih cepat. ketika perusahaan berada dibawah titik target maka perusahaan menerbitkan utang jangka panjang yang lebih murah dibandingkan dengan perusahaan-perusahann dalam kelompok yang tidak patuh prinsip syariah. Perusahaan yang patuh prinsip Syariah mampu menghasilkan kualitas utang meningkatkan utang jangka panjang dengan harga lebih murah. Namun hasil pengujian juga menunjukkan adanya potensi biaya agensi yang lebih tinggi berupa asimetri informasi yang lebih besar untuk perusahaan yang patuh terhadap prinsip Syariah. 
Perusahaan secara operasional patuh pada Syariah memiliki kinerja jauh lebih menguntungkan daripada perusahaan tidak termasuk kelompok yang patuh pada Syariah. Perusahaan yang termasuk kelompok patuh pada Syariah memiliki Margin laba operasi yang lebih tinggi karena struktur biaya yang lebih rendah, perputaran total aset atau efisiensi yang lebih tinggi (Akguc and Al Rahahleh, 2018). Profitabilitas berhubungan negatif terhadap leverage (Rajan dan Zingales, 1995; Wald, 1999; Booth et al., 2001; Chen, 2004; Bauer, 2004; Viviani, 2008; Öztekin, 2015; Guner, 2016, Sahudin et al, 2019; Arif dan Mai, 2020).

\section{Ha $_{6}$ : Profitabilitas memiliki pengaruh negatif signifikan terhadap book leverage.}

\section{Tangibility}

Tangibilitas aset didefinisikan sebagai rasio aset tetap bersih dibanding total aset. Tangibilitas perusahaan menjadi salah satu faktor penentu yang juga memberikan hasil konsisten terhadap struktur modal (Yildirim et al., 2018). Rasio ini mengidikasikan tingkat keamanan bagi kreditur atas dana yang ditanamkan diperusahaan. Semakin tinggi nilai rasio aset bersih dibanding total aset maka semakin tinggi tingkat keamanannya bagi kreditur ketika terjadi kebangkrutan dengan melikuidasi aset sebagai hipotek. Teori trade-off menjelaskan adanya hubungan positif antara tangibilitas aset dan leverage (Jacinta Chan Phooi M'ng, 2017, R. Angayarkanni, 2018).

Ahmed (2007) berpendapat bahwa hutang harus didukung oleh aset berwujud, dalam artian perusahaan dibatasi hanya dapat melakukan hutang dibawah jumlah nilai aset berwujud yang dimilikinya. Perusahaan yang memiliki aset ber- wujud banyak juga mengindikasikan bahwa perusahaan dapat mendapatkan hutang yang tinggi.

Dengan demikian, semakin banyak aset berwujud perusahaan maka kolateral atau jaminan yang dimiliki perusahaan juga lebih banyak, kondisi ini tentu memudahkan manajemen perusahaan untuk memilih pendanaan dari hutang daripada sumber pendanaan lainnya. Rasio utang atas aset berhubungan positif dengan tangibilitas aset (Qiu, Mei and La, Bo, 2010)

Hipotesis yang diajukan dalam penelitian ini didukung oleh hasil penelitian anatar lain (misalnya Jensen and Meckling, 1976; Titman and Wessels, 1988; Jensen et al., 1992; Rajan and Zingales, 1995; Chen et al., 1998; Bevan and Danbolt, 2001; M'ng et al., 2017; Sahudin et al., 2019 dan Arif dan Mai, 2020).

\section{Ha7: Tangibilitas memiliki pengaruh positif signifikan terhadap book leverage.}

\section{Ukuran perusahaan}

Ukuran perusahaan ditemukan sebagai salah satu faktor penentu yang memiliki hubungan positif dengan struktur modal persahaan (Rajan dan Zingales, 1995). Rajan dan Zingales (1995) berpendapat bahwa perusahaan yang lebih besar cenderung lebih beragam lini bisnisnya dan karena itu kecil kemungkinannya perusahaan tersebut bangkrut. Akibatnya, ukuran perusahan memiliki hubungan positif dengan leverage.

Ukuran perusahaan yang besar juga menunjukkan kestabilan dalam arus kas, dan perusahaan yang lebih besar dapat menerbitkan utang dengan biaya lebih rendah daripada perusahaan kecil. Studi empiris menunjukkan hubungan positif antara ukuran perusahaan dengan leverage perusahaan. Seperti, Rajan dan Zingales, 
1995; Booth et al, 2001; Akhtar dan Oliver, 2009.

Ha8: Ukuran perusahaan memiliki pengaruh positif signifikan terhadap book leverage.

Peran Ukuran Perusahaan sebagai Moderator

Terdapat sudut pandang yang saling berlawanan tentang ukuran perusahaan. Perusahaan yang lebih besar dengan profitabilitas yang sama dengan perusahaan yang lebih kecil mendapatkan lebih banyak pembiayaan eksternal karena ketersediaan aset yang lebih nyata (Mazhar \& Nasr 2010). Perusahaan kecil lebih sensitif terhadap pembiayaan internal untuk pertumbuhan dibandingkan dengan perusahaan besar. Perusahaan kecil lebih sulit untuk mengakses layanan keuangan karena informasi dan biaya transaksi yang lebih besar. (Rafiq et al, 2008). Oleh karena itu, ukuran perusahaan dianggap sebagai moderator yang berinteraksi dengan hubungan antara leverage dan variabel independen dalam model empiris.

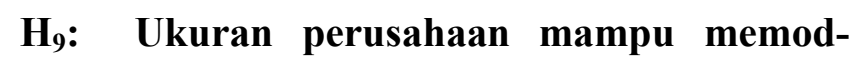
erasi hubungan antara variabel business risk, terhadap book leverage.

$\mathrm{H}_{10}$ :Ukuran perusahaan mampu memoderasi hubungan antara variabel dividend payout ratio terhadap book leverage.

$\mathrm{H}_{11}$ :Ukuran perusahaan mampu memoderasi hubungan antara variabel growth opportunities terhadap book leverage.

$\mathrm{H}_{12}$ :Ukuran perusahaan mampu memoderasi hubungan antara variabel kepatuhan syariahterhadap book leverage.

$H_{13}$ :Ukuran perusahaan mampu memoderasi hubungan antara non-debt tax shield terhadap book leverage.

$\mathrm{H}_{14}$ :Ukuran perusahaan mampu memoderasi hubungan antara variabel profitabilitas terhadap book leverage.

$\mathrm{H}_{15}$ :Ukuran perusahaan mampu memoderasi hubungan antara tangibilitas terhadap book leverage.

\section{METODE PENELITIAN}

\section{Jenis Penelitian}

Penelitian ini termasuk penelitian kuantitatif. Data-data yang digunakan berupa angkaangka yang akan diolah menggunakan bantuan software Eviews. Data yang telah diolah akan diinterpretasikan sesuai hasil olah data. Penelitian ini menggunakan book leverage sebagai proksi strukutur modal perusahaan menjadi variabel terikat, sedangkan variabel bebasnya meliputi dividend payout ratio, kepatuhan syariah, risiko bisnis, peluang pertumbuhan (growth opportunities), non debt tax shield, profitabilitas dan tangibilitas serta akan dimoderasi dengan variabel ukuran perusahaan.

\section{Populasi dan Sampel}

Penelitian ini menggunakan populasi dari perusahaan yang listing pada indeks IDX30 sejak pertama kali diluncurkan sampai dengan tahun 2019. Sumber data yang digunakan dalam penelitian ini adalah sumber data sekunder yang diperoleh dari berbagai literature artikel, laporan keuangan serta melalui websute resmi Bursa Efek Indonesia maupun website emiten yang terpilih menjadi sampel data. Penelitian ini juga mereview penelitian sebelumnya serta teori-teori yang ada untuk dijadikan pengayaan landasan teori.

Sampel data diambil menggunakan metode purposive sampling. Ada kriteria-kriteria tertentu yang dipersyaratkan untuk menjadi sampel dari populasinya. Setelah melakukan seleksi sesuai 
kriteria yang diajukan, maka hasil pemilihan sampel ditampilkan pada tabel 1. Sampel dalam penelitian ini menggunakan 15 perusahaan dengan periode waktu 8 tahun, sehingga sampel yang digunakan 120 sampel.

Tabel 1

Seleksi pemilihan sampel

\section{Model}

Model yang dibangun pada penelitian ini ada dua, yaitu tanpa moderasi variabel ukuran perusahaan dan dengan moderasi variabel ukuran perusahaan. Model yang tanpa moderasi, diolah dangkan model dengan moderasi dengan menggunakan Moderated Regression Analysis (MRA), model yang dimaksud adalah sebagai berikut :

\section{Model Tanpa Moderasi}

$\mathrm{Y}_{\mathrm{it}}=\alpha+\beta_{1} \mathrm{BR}_{\mathrm{it}}+\beta_{2} \mathrm{DPR}_{\mathrm{it}}+\beta_{3} \mathrm{GO}_{\mathrm{it}}+\beta_{4} \mathrm{KS}_{\mathrm{it}}$ $+\beta_{5}$ NDTS $_{\text {it }}+\beta_{6}$ ROA $_{\text {it }}+\beta_{7}$ SIZE $_{i t}+\beta_{8}$ TAN $_{\text {it }}+$ $\varepsilon_{\text {it }}$

\begin{tabular}{|c|c|c|}
\hline $\begin{array}{l}\mathbf{N} \\
\mathbf{0}\end{array}$ & Kriteria & $\begin{array}{l}\text { Jumla } \\
\text { h } \\
\text { Perus } \\
\text { ahaan }\end{array}$ \\
\hline 1 & $\begin{array}{l}\text { Perusahaan yang masuk seleksi } \\
\text { indeks IDX30 sejak diluncur- } \\
\text { kan sampai tahun } 2019\end{array}$ & 61 \\
\hline 2 & $\begin{array}{l}\text { Perusahaan yang listing namun } \\
\text { tidak konsisten pada indeks } \\
\text { IDX30 sejak diluncurkan sam- } \\
\text { pai tahun } 2019\end{array}$ & (46) \\
\hline 3 & Sub jumlah & 15 \\
\hline \multirow[t]{2}{*}{4} & $\begin{array}{l}\text { Periode waktu penelitian 2012- } \\
2019 \text { (selama } 8 \text { tahun } \times 15 \\
\text { perusahaan) }\end{array}$ & 120 \\
\hline & $\begin{array}{l}\text { Jumlah total sampel yang } \\
\text { digunakan dalam penelitian }\end{array}$ & 120 \\
\hline
\end{tabular}
menggunakan teknik regresi data panel, se-

$\mathrm{Y}_{\mathrm{it}}=\alpha+\beta_{1} \mathrm{BR}_{\mathrm{it}}+\beta_{2} \mathrm{DPR} \mathrm{it}_{\mathrm{it}}+\beta_{3} \mathrm{GO}_{\mathrm{it}}+\beta_{4} \mathrm{KS}_{\mathrm{it}}+$ $\beta_{5}$ NDTS $_{\text {it }}+\beta_{6}$ ROA $_{\text {it }}+\beta_{7}$ SIZE $_{\text {it }}+\beta_{8}$ TAN $_{\text {it }}+\beta_{9}$ BR*SIZE ${ }_{\text {it }}+\beta_{10}$ DPR $^{*} \operatorname{SIZE}_{\mathrm{it}}+\beta_{11} \mathrm{GO}^{*} \mathrm{SIZE}$ it + $\beta_{12} \mathrm{KS}^{*} \mathrm{SIZE}$ it $+\beta_{13}$ NDTS*SIZE it $+\beta_{14}$ $\mathrm{ROA}^{*} \mathrm{SIZE}_{\text {it }}+\beta_{15}$ TAN*SIZE $_{\text {it }}+\varepsilon_{\text {it }}$

\section{Dimana :}

$\mathrm{Y} \quad=$ book leverage/DAR

$\beta_{1-15}=$ koefisien regresi

$\mathrm{DPR}_{\mathrm{it}}=$ Dividend Payout Ratio

$\mathrm{BR}_{\mathrm{it}} \quad=$ Business Risk

$\mathrm{GO}_{\text {it }}=$ Growth Opportunity atau peluang pertumbuhan

$\mathrm{KS}_{\mathrm{it}} \quad$ =kepatuhan syariah (variabel dummy)

NDTS ${ }_{\mathrm{it}}=$ non-debt tax shield

$\mathrm{ROA}_{\mathrm{it}}=$ profitabilitas

SIZE $_{\text {it }}=$ ukuran perusahaan

$T A N_{\text {it }}=$ tangibility

(variabel bebas)*SIZEit $=$ interaksi antara ukuran perusahaan dengan variabel bebas perusahaan

\section{$\varepsilon_{\text {it }} \quad=$ error terms}

\section{Tabel 2. Definisi Operasional Variabel}

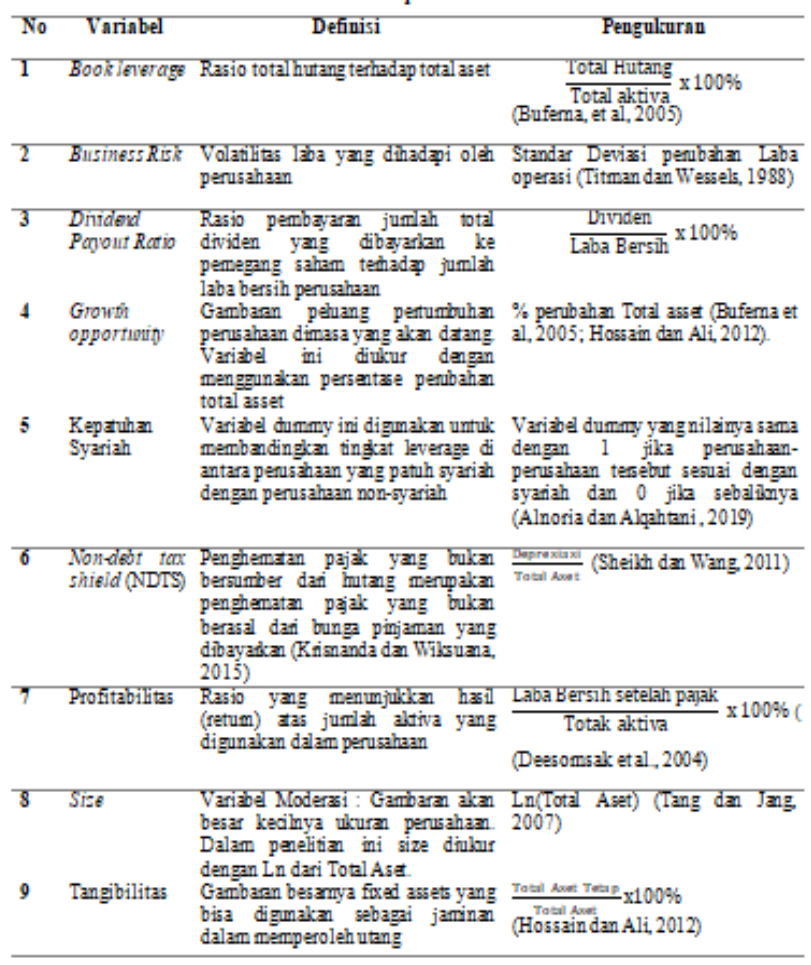

\section{Model dengan Mederasi}




\section{Teknik Analisis Data}

Teknik menganalisis data pada model yang tanpa moderasi yaitu menggunakan regresi data panel melalui pendekatan OLS (common effect), fixed effect dan random effect. Dari hasil ketiga pendekatan akan ditentukan model mana yang terbaik berdasarkan uji Chow, Uji Hausman dan Uji Langrage Multiplier. Sedangkan model yang dengan moderasi akan dianalisis dengan Moderated Regression Analysis (MRA) pada aplikasi Eviews.

\section{HASIL DAN PEMBAHASAN}

\section{Analisis Deskripsi Data Penelitian}

Data sampel yang diperoleh setelah melakukan seleksi sampel dengan metode pusposive sampling sebanyak 15 sampel perusahaan seperti yang ditampilkan pada tabel 1. Deskripsi data statistik dapat dilihat pada tabel 3.

\section{Tabel 3. Deskripsi Statistik}

$\begin{array}{ccccccccc}\text { DAR } & \text { BR } & \text { DPR } & \text { GO } & \text { KS } & \text { ROA } & \text { NDTS } & \text { SIZE } & \text { TAN } \\ 0.527 & 14.422 & 48.087 & 0.102 & 0.658 & 9.742 & 0.220 & 18.830 & 0.283 \\ 0.475 & 14.385 & 44.935 & 0.094 & 1.000 & 6.690 & 0.179 & 18.404 & 0.261 \\ 0.880 & 19.178 & 138.55 & 0.921 & 1.000 & 46.520 & 0.873 & 22.795 & 0.709 \\ 0.130 & 11.249 & 7.5300 & -0.330 & 0.000 & 1.330 & 0.007 & 15.673 & 0.003 \\ 0.237 & 1.536 & 22.457 & 0.125 & 0.476 & 9.539 & 0.195 & 1.708 & 0.219 \\ 0.170 & 0.822 & 1.232 & 3.0516 & -0.667 & 2.036 & 1.259 & 0.422 & 0.351 \\ 1.862 & 4.514 & 5.070 & 22.520 & 1.445 & 7.038 & 4.704 & 2.440 & 2.026 \\ 120 & 120 & 120 & 120 & 120 & 120 & 120 & 120 & 120\end{array}$

Variabel GO (growth opportunitiesi) dan ROA merupakan variabel yang memiliki nilai standar deviasi lebih besar dari nilai rata-rata (mean), ini mengindikasikan bahwa sebaran data pada variabel tersebut kurang menyebar secara merata. Sedangkan untuk variabel lain, data diatas telah menunjukkan sebaran yang baik.

Tabel 4 menunjukkan pengujian terhadap gejala multikolinearitas, dari data diatas hubungan antar variabel menunjukkan tidak ada yang melebihi diatas angka 0.80, maka dari itu bisa disimpulkan bahwa model yang dibangun ini terbebas dari gejala multikolinearitas.
Tabel 4. Koefisien Matriks Korelasi

\section{Pearson}

\begin{tabular}{lrrrrrrrrr}
\hline Correlation & \multicolumn{1}{l}{ DAR } & BR & \multicolumn{1}{l}{ DPR } & \multicolumn{1}{l}{ GO } & \multicolumn{1}{l}{ KS } & ROA & NDTS & SIZE & TAN \\
\hline DAR & 1 & & & & & & & & \\
BR & 0.360 & 1 & & & & & & & \\
DPR & -0.368 & -0.083 & 1 & & & & & & \\
GO & 0.016 & -0.057 & -0.160 & 1 & & & & & \\
KS & -0.696 & -0.189 & 0.310 & 0.064 & 1 & & & & \\
ROA & -0.256 & -0.238 & 0.359 & -0.037 & 0.430 & 1 & & & \\
NDTS & -0.622 & 0.029 & 0.444 & -0.045 & 0.597 & 0.184 & 1 & & \\
SIZE & 0.604 & 0.786 & -0.291 & -0.016 & -0.492 & -0.546 & -0.276 & 1 & \\
TAN & -0.618 & -0.234 & 0.486 & -0.001 & 0.651 & 0.545 & 0.750 & -0.547 & 1 \\
\hline
\end{tabular}

Tabel 5. Hasil Uji Chow, Uji Hausman dan Uji LM

\begin{tabular}{|c|c|c|c|c|c|c|}
\hline \multirow{2}{*}{ Modek } & \multicolumn{2}{|c|}{ Chow Test } & \multicolumn{2}{|c|}{ Hausman Test } & \multicolumn{2}{|c|}{ Lagnage Multiplier Test } \\
\hline & statistic & prob. & statistic & prob. & statistic & prob. \\
\hline Model Tapa Modersi & 356.996 & 0.000 & 12.070 & 0.1481 & 291.414 & 0.000 \\
\hline Modd Modenai & 361.274 & 0.000 & 10211 & 0.176 & 307.157 & 0.000 \\
\hline
\end{tabular}

Tabel 5 menyajiikan hasil dari penentuan model terbaik dari ketiga model yang diuji, model ini nanti akan digunakan untuk intepretasi hasil penelitian. Semua model yang dibangun menunjukkan bahwa Random Effect Model adalah model terbaik pada regresi data panel dalam penelitian ini. Dari tabel 5, uji Chow menunjukkan bahwa Fixed Effect Model lebih baik daripada Common Effect Model yang dibuktikan dengan nilai probabilitasnya dibawah 5\%, kemudian dilakukan uji Hausman dengan hasil probabilitas diatas 5\%, maka model yang lolos adalah Random Effect Model daripada Fixed Effect Model. Uji model terakhir adalah uji Langrange Multiplier (LM) yang menunjukkan bahwa Random Effect Model sebagai model terbaik dalam penelitian ini dengan nilai probabilitas yang ditunjukkan dibawah 5\%, yang artinya memilih Random Effect Model daripada Common Effect Model.

Hasil regresi random effect dengan dua model menunjukkan bahwa adjusted R-squared sebelum ada moderasi dari variabel ukuran perus- 
ahaan yaitu sebesar 0,425 atau 42,5\% model yang dibangun mampu menjelaskan hubungan antara variabel bebas dengan variabel terikat. Sedangkan dengan model yang diberi variabel moderasi, angka adjusted R-squared menunjukkan sebesar 0,400 atau 40,0\% model ini mampu menjelaskan hubungan antara variabel terikat dengan variabel bebasnya.

\section{Diskusi Hasil Penelitian}

Dari hasil olah data yang telah dilakukan dengan model Random Effect, penelitian ini menemukan bahwa terdapat hubungan yang signifikan antar variabel bebas dengan variabel struktur modal. Dari hasil analisis data, variabel risiko bisnis memiliki pengaruh yang positif signifikan terhadap struktur modal pada level kepercayaan 5\%. Hasil penelitian ini tidak sejalan dengan teori yang diharapkan yaitu hubungan negative dengan tingkat hutang. Hasil ini dapat disebabkan karena banyak hal, contohnya adanya variasi suku bunga, kebijakan moneter dari Bank Indonesia yang turut mempengaruhi, situasi politik yang kurang stabil dan keadaan ekonomi (Sheikh dan Qureshi, 2017). Menurut Tang dan Jang (2007), perusahaan akan berusaha untuk mentransfer risiko keuangan yang disebabkan oleh volatilitas laba dari pemegang saham ke pemberi pinjaman dengan menggunakan lebih banyak hutang, yang akibatnya menghasilkan korelasi positif risiko bisnis dengan hutang. Variabel moderasi ukuran perusahaan yang lebih tinggi juga memungkinkan pengaruhnya untuk melakukan transfer risiko tersebut. Penelitian ini sejalan dengan Esperanca et al (2003), Tang dan Jang (2007), dan Malinic et al (2013) dan Sheikh dan Qureshi (2017). nyai hubungan yang negative signifikan pada level $<5 \%$ yaitu sebesar $0,01 \%$. Temuan ini bertentangan dengan harapan teoritis, temuan ini mengindikasikan bahwa, rendahnya dividen yang dibagikan kepada pemegang saham maka menunjukkan profit yang didapatkan perusahaan juga rendah, hal ini memaksa kebutuhan sumber dana pembiayaan operasi perusahaan bersumber dari hutang bukan dari laba yang dihasilkan. Temuan ini sejalan dengan Mazer (2007) pada total sampel data, Bopkin dan Arko (2009), Mohammad dan Suhadak (2015) dan Eviani (2015).

Pada penelitian ini tidak menemukan hasil yang signifikan pada variabel growth opportunities, baik sebelum dimoderasi maupun setelah dimoderasi oleh ukuran perusahaanl. Perusahaan tidak mempertimbangkan faktor peluang pertumbuhan dimasa depan untuk melakukan pendanaan perusahaan. Hasil dari penelitian ini sejalan dengan hasil penelitian oleh Titman \& Wessels (1988), Chen (2003), Sheikh \& Wang (2010) dan Hossain \& Ali (2012).

Di lain sisi, penelitian ini berhasil mengungkapkan bahwa perusahaan yang patuh pada aturan syariah memiliki tingkat hutang yang lebih rendah. Variabel dummy ini memberikan bukti bahwa jika perusahaan sesuai dengan aturan syariah yang disusun oleh Dewan Syariah Nasional-Majelis Ulama Indonesia, perusahan tersebut memiliki tingkat hutang yang rendah. Hasil ini sejalan dengan penelitian oleh Arif dan Mai (2020), Alnoria dan Alqahtani (2019), Farooq and Tbeur (2013) dan Akinsomi et al. (2015). Kriteriakriteria dalam aturan DSN-MUI salah satunya membatasi perusahaan untuk melakukan hutang yang berlebihan, sehingga mengurangi risiko ke- 
ngakrutan perusahaan.

Penelitian ini mengungkapkan bahwa faktor perisai pajak non hutang (NDTS) memiliki pengaruh yang signifikan negative terhadap book leverage pada tingkat kepercayaan $<1 \%$. Perusahaan yang memiliki keunggulan pada nilai perisai pajak non hutang yang tinggi dapat dimanfaatkan untuk menekan jumlah hutang yang digunakan untuk pendanaan. Pilihan hutang dilakukan oleh perusahaan salah satunya dengan alas an untuk mendapatkan perlindungan pajak, sehingga berakibat hutang yang membengkak. Namun, ketika perusahaan memiliki nilai NDTS yang tinggi, pilihan tidak jatuh lagi ke hutang, tetapi memanfaatkan faktor NDTS tersebut. Penelitian ini mendukung penelitian yang dilakukan oleh Wald (1999), Deesomsak et al. (2004) dan Viviani (2008), Akhtar dan Oliver (2009).

Sesuai hipotesis yang diajukan, dalam penelitian ini menemukan bahwa profitabilitas perusahaan memiliki pengaruh negative terhadap book leverage perusahaan. Dengan kata lain, semakin tinggi laba yang dihasilkan perusahaan, maka penggunaan hutang perusahaan semakin ditekan atau rendah. Segaris lurus dengan teori pecking order, bahwa ketika laba memungkinkan untuk digunakan sebagai sumber pendanaan, maka opsi penggunaan sumber eksternal dapat dihindari. Penelitian ini semakin menguatkan hasil penelitian yang telah dilakukan sebelumnya, yaitu Booth et al (2001); Chen (2004); Bauer ( 2004); Viviani (2008); Öztekin (2015); Guner (2016), Sahudin et al (2019) dan Arif dan Mai ( 2020).

Variabel tangibilitas tidak berpengaruh signifikan terhadap struktur modal. Penelitian ini melaporkan hasil yang sama dengan, Wiwattanakantang (1999), Deesomsak et al (2004), Buferna et al (2005) dan Ibrahim et al (2015). Tinggi rendahnya asset tetap yang dimiliki oleh perusahaan pada hasil penelitian ini tidak mempengaruhi besaran dan keputusan struktur modal perusahaan. Namun, hasil berbeda didapatkan ketika adanya moderasi dari ukuran perusahaan, tangibilitas memiliki pengaruh positif yang signifikan pada level $<5 \%$ terhadap struktur modal perusahaan. Perubahan hasil ini karena besarnya ukuran perusahaan, memungkinkan perusahaan memiliki banyak asset tetap yang dimiliki, sehingga hal ini dapat memicu manajmeen untuk untuk mendapatkan hutang yang lebih besar dibandingkan dengan perusahaan yang lebih kecil. Hasil ini sesuai dengan hasil oleh Bevan and Danbolt (2001); M'ng et al. (2017); Sahudin et al. (2019) dan Arif dan Mai (2020).

Variabel ukuran perusahaan (size) dalam penelitian ini terbukti memliki pengaruh positif signifikan terhadap book leverage dengan level kepercayaan 5\%. Ini sesuai dengan hipotesis dan teori yang diharapkan, bahwa perusahaan yang berukuran besar cenderung cenderung memiliki diversifikasi bisnis yang beragam serta memiliki pondasi yang kuat, sehingga kecil kemungkinan akan berisiko bangkrut. Hal ini menyebabkan dari sisi perusahaan juga dengan mudah mendapatkan akses pendanaan hutang serta dari sisi peminjam juga semakin percaya daripada perusahaan yang berukuran lebih kecil. Hasil pada penelitian ini sejalan dengan penelitian yang dilakukan oleh Rajan dan Zingales (1995); Booth et al (2001) dan Akhtar dan Oliver (2009). 


\section{Diskusi Pengaruh Moderasi}

Interaksi antara variabel-variabel bebas dengan variabel ukuran perusahaan terhadap book leverage menunjukkan hasil yang beragam. Ukuran perusahaan turut mempengaruhi pengaruh risiko bisnis dengan tingkat hutang, perusahaan yang memiliki ukuran besar dengan risiko bisnis yang besar maka perusahaan akan berhutang yang lebih banyak. Besarnya perusahaan dengan pengalaman dan kemampuan bisnis yang besar, serta memiliki pondasi yang kuat menyebabkan perusahaan untuik memperbanyak hutangnya dalam pendanaan operasional mereka. Temuan ini sejalan dengan kuadratik risiko pada penelitian Crutchley, et al (1999).

Ukuran perusahaan yang besar akan memiliki banyak kekuatan dalam mengembangkan usaha, dengan hal ini perusahaan akan mampu membayar dividen lebih banyak kepada pemegang saham. Sebaliknya perusahaan kecil kemampuan bisnis yang terbatas, akan memberikan hasil dividen yang kecil pula pada pemegang saham, sehingga ketika dividen yang dibagi sedikit mengindikasikan bahwa perusahaan memiliki persediaan laba ditahan yang rendah, dan membutuhkan banyak hutang untuk membiaya usahanya. Hasil ini sejalan dengan Ramachandran dan Packkirisamy (2010).

Ukuran perusahaan gagal memoderasi variabel growth opportunities terhadap struktur modal. Perusahaan yang lebih besar ataupun kecil tidak menggunakan leverage untuk mengusulkan pertumbuhan perusahaan. Interaksi juga tidak terjadi pada ukuran perusahaan dengan kepatuhan syariah, besar ataupun kecil ukuran perusahaan maka perusahaan yang yang patuh syariah akan tetap menjalankan kebijakan sesuai dengan aturan syariah. Dengan demikian, besar kecilnya ukuran perusahaan, tidak berpengaruh pada keputusan struktur modal perusahaan pada perusahaan yang patuh aturan syariah.

Temuan yang menarik ketika ukuran perusahaan memoderasi hubungan tangibilitas dengan struktur modal, karena tanpa moderasi ukuran, variabel tangibilitas tidak signifikan terhadap struktur modal. Hal ini berarti perusahaan yang lebih besar dengan aset yang lebih banyak dalam struktur modal akan menggunakan banyak leverage sedangkan perusahaan yang lebih kecil dengan aset yang lebih banyak akan lebih suka menggunakan lebih sedikit leverage.

Peran yang efektif juga ditunjukkan oleh ukuran perusahaan yang memiliki depresiasi aset yang tinggi, ukuran perusahaan yang besar dan asset yang dimilika banyak, dipengaruhi oleh beasran depresiasi dan amortisasi asset. Semakin besar ukuran perusahaan, dengan NDTS yang tinggi, maka pendanaan perusahaan dari modal akan semakin rendah, karena persuhaan memiliki banyak manfaat dari nilai NDTS dan ukuran asset yang banyak. Temuan ini sejalan dengan teori trade off dan teori agensi. Perusahaan harus mampu menyeimbangkan nilai manfaat dari perisai pajak dan besarnya ukuran perusahaan turut mengawasi manajemen untuk menekan tingkat hutang agar memanfaatkan perisai pajak non hutang.

\section{SIMPULAN}

Penelitian ini bertujuan untuk menguji faktor-faktor apa saja yang memiliki pengaruh terhadap leverage perusahaan. Dari hasil analisis data dapat disimpulkan bahwa variabel perisai 
hutang non pajak dan profitabilitas memiliki pengaruh yang signifikan negatif pada tingkat kepercayaan $<1 \%$ terhadap book leverage perusahaan. Variabel risiko bisnis dan ukuran perusahaan juga berpengaruh signifikan positif pada tingkat kepercayaan $<5 \%$ terhadap book leverage perusahaan. Kemudian variabel divident payout rasio dan kepatuhan syariah berpengaruh negatif signifikan pada taraf kepercayaan $<5 \%$ terhadap book leverage perusahaan. Sedangkan, tangibilitas dan peluang pertumbuhan masa depan tidak berpengaruh terhadap book leverage perusahaan.

Perusahaan yang masuk kategori syariah, terbukti lebih berhati-hati dalam mengambil kebijakan pendanaan dari sumber eksternal. Perusahaan tersebut memiliki tingkat hutang yang lebih rendah dibanding perusahaan non syariah. Temuan ini menunjukkan bahwa perusahaan syariah memang lebih aman jika dilihat dari porsi kepemimlikan hutangnya. Dilihat dari arah keofisien yang dihasilkan, perusahaanperusahaan yang terdaftar di IDX30 Bursa Efek Indonesia, memiliki kecenderungan yang berimbang, dimana variabel profitabilitas, NDTS mewakili teori pecking order, sedangkan ukuran perusahaan, tangibilitas mewakili teori trade off sedangkan dividend payout rasio dan kepatuhan syariah mewakili teori agensi. Mengacu pada hasil penelitian ini, perusahaan diharapkan mengutamakan kepentingan pemegang saham dengan berhati-hati dalam melakukan penentuan kebijakan struktur modalnya, perusahaan sebaiknya menggunakan sumber eksternal ketika kondisi perusahaan dalam keadaan mendukung, seperti laba yang ditahan tidak mencukupi, tidak tersedianya alternatif perisai pajak non hutang, besaran perusahaan yang belum kokoh dan lainlainnya. Kebijakan struktur modal yang ideal diharapkan mampu meningkatkan kesejahteraan pemegang saham dan manajemen perusahaan.

Ukuran perusahaan mampu memoderasi semua variabel kecuali peluang pertumbuhan dimasa depan dan kepatuhan syariah. Perusahaan besar dan kecil tidak mempengaruhi kebijakan manajemen dalam hal mematuhi aturan syariah, hal ini menunjukkan bahwa perusahaan beranbenar taat dan konsisten dengan prinsip yang berlaku. Perusahaan yang besar dan kecil juga tidak mempengaruhi kebijakan manajemen dalam mendorong pertumbuhan dimasa mendatang dengan melakukan penggunaan hutang.

Penelitian ini tentu memiliki keterbatasan, dengan masih rendahnya adj $\mathrm{R}$ square masih berpeluang diisi oleh penelitian selanjutnya dengan variabel lain yang secara teori memiliki dampak bagi kebijakan struktur modal, seperti likuiditas atau klasifikasi industri perusahaan.

\section{DAFTAR PUSTAKA}

Ahmad, Noryati \& Azhar, Noor. 2015. Investigating of Shariah Compliant Companies Capital Structure Determinants. Advanced Science Letters.21. 1986-1989. 10.1166/ as1.2015.6180.

Akhtar, S., \& Oliver, B. 2009. Determinants of capital structure for Japanese multinational and domestic corporations. International Review of Finance, 9(1-2), 1-26. https:// doi.org/10.1111/irfi.2009.9.issue-1-2

Alnori, F., \& Alqahtani, F. 2019. Capital structure and speed of adjustment in non-financial firms: Does sharia compliance matter? Evidance form Saudi Arabia, Emerging Ma- 
rkets Review, 39, 50-67.

András Danis, Daniel A.Rettl, Toni M. Whited, Refinancing, profitability, and capital structure, Journal of Financial Economics, Volume 114, Issue 3, December 2014, Pages 424-443

Arif, I. A., \& Mai, M. (2020). The Determinants of Capital Structure: A Comparative Study between Sharia and Non-Sharia Manufacturing Companies in Indonesia Stock Exchange (IDX). International Journal of Applied Business Research, 2(01), 73-85. https://doi.org/10.35313/ijabr.v0i0.67

Azhagaiah, Ramachandran \& Veeramuthu, Packkirisamy. (2010). The Impact of Firm Size on Dividend Behaviour: A Study With Reference to Corporate Firms across Industries in India. Managing Global Transitions. 8.

Bevan, A. A., \& Danbolt, J. 2001. On the determinants and dynamics of UK capital structure.

Bhaduri S. (2002). Determinants of corporate borrowing: some evidence from the Indian corporate structure, Journal of Economic and Finance, 26, 200-215

Bokpin, G.A. and Arko, A.C. 2009. Ownership structure, corporate governance and capital structure decisions of firms: Empirical evidence from Ghana, Studies in Economics and Finance, Vol. 26 No. 4, pp. 246-256. https://

doi.org/10.1108/10867370910995708

Booth, L., Aivazian, V., Demiguc-Kunt, A., \& Maksimovic, V. 2001. Capital structures in developing countries. Journal of Finance, 56(1), 87-130.
Buferna, F. M., Bangassa, K., \& Hodgkinson, L. 2005. Determinants of capital structure: evidence from Libya (Vol. 8). University of Liverpool.

Burgman, T. A. (1996). An empirical examination of multinational corporate capital structure. Journal of international business studies, 27(3), 553-570.

Chen, J. J. 2004. Determinants of capital structure of Chinese-listed companies. Journal of Business research, 57(12), 1341-1351.

Crutchley, C. E., Jensen, M. R., Jahera Jr, J. S., \& Raymond, J. E. (1999). Agency problems and the simultaneity of financial decision making: The role of institutional ownership. International review of financial analysis, 8(2), 177-197.

Dan Dhaliwal, J. Scott Judd, Matthew Serfling, Sarah Shaikh, Journal of Accounting and Economics, Vol. 61, No: 1, 23-48

De Miguel, A., \& Pindado, J. 2001. Determinants of capital structure: new evidence from Spanish panel data. Journal of corporate finance, 7(1), 77-99.

DeAngelo, H., \& Masulis, R. W. 1980. Optimal capital structure under corporate and personal taxation. Journal of Financial Economics, $\quad 8(1), \quad 3-29 . \quad \mathrm{https}: / /$ doi.org/10.1016/0304-405X(80)90019-7

Deesomsak, R., K. Paudyal, dan G. Pescetto. 2004. The determinants of capital structure: evidence from the Asia Pacific region. Journal of Multinational Finance Management 14(4-5): 387-405. http://doi.org/10.1016/ j.mulfin.2004.03.001. 
Esperanca, J. P., Gama, A. P. M., \& Gulamhussen, M. A. 2003. Corporate debt policy of small firms: an empirical (re) examination. Journal of Small Business and Enterprise Development.

Eunju Yoon and SooCheong Jang, 2013, The Effect of Financial Leverage on Profitability and Risk of Restaurant Firms, The Journal of Hospitality Financial Management. Vol. 13, 2005 - Issue 1, 35-47

Eviani, A. D. 2015. Pengaruh Struktur Aktiva, Pertumbuhan Penjualan, Dividend Payout Ratio, Likuiditas dan Profitabilitas Terhadap Struktur Modal. Jurnal Akuntansi dan Sitem Teknologi Informasi, 11 (2):194202.

Farooq, O., \& Tbeur, O. 2013. Dividend policies of shariah-compliant and non-shariahcompliant firms: evidence from the MENA region. International Journal of Economics and Business Research, 6(2), 158-172.

Fischer, E. O., Heinkel, R., \& Zechner, J. 1989. Dynamic capital structure choice: Theory and tests. The Journal of Finance, 44(1), 1940. https://doi.org/10.1111/j.15406261.1989.tb02402.x

Frank, M. Z., \& Goyal, V. K. (2004). The effect of market conditions on capital structure adjustment. Finance Research Letters, 1(1), 47-55.

Furi, V. R., dan Saifudin. 2012. Faktor-Faktor yang Mempengaruhi Struktur Modal ( Studi Empiris Pada Perusahaan Manufaktur yang Terdaftar di BEI Tahun (2009 2010 ). JURAKSI 1(2): 49-62.

Güner, A. (2016). The determinants of capital structure decisions: New evidence from
Turkish companies. Procedia economics and finance, 38, 84-89.

Handoo, A., \& Sharma, K. (2014). A study on determinants of capital structure in India. IIMB Management review, 26(3), 170182.

Hatzinikolaou, D., Katsimbris, G. M., \& Noulas, A. G. 2002. Inflation uncertainty and capital structure: Evidence from a pooled sample of the Dow-Jones industrial firms. International Review of Economics \& Finance, 11(1), 45-55. https://doi.org/10.1016/S1059-0560 (01)00085-5

Hirschleifer, D. I., \& Thakor, A. (1989). Managerial reputation, project choice and dept. Anderson Graduate School of Management at UCLA, Working Paper, 14-89.

Hossain, F., \& Ali, A. 2012. Impact of firm specific factors on capital structure decision: an empirical study of Bangladeshi Companies. International Journal of Business Research and Management, 3(4), 163-182.

Ilyukhin, Evgeny, The Determinants of Capital Structure: Evidence from Russia (May 25, 2017). http://dx.doi.org/10.2139/ ssrn. 2974213

Jacinta Chan Phooi M'ng, 2017, Mahfuzur Rahman and Selvam Sannacy, The determinants of capital structure: Evidence from public listed companies in Malaysia, Singapore and Thailand, Cogent Economics \& Finance, 5: 1, 1-34

Jana Stekla and Marta Grycova, 2016, The relationship between profitability and capital structure of the agricultural holdings in the Czech Republic. Agricultural Economics, 
62:9: $421-428$

Jensen, M. (1986). Agency costs of free cash flow, corporate finance and takeovers. American Economic Review, 76(2), $323 \mathrm{e} 329$.

Jensen, M. C., \& Meckling, W. H. 1979. Theory of the firm: Managerial behavior, agency costs, and ownership structure. In Economics social institutions (pp. 163-231). Springer, Dordrecht.

John R. Graham, Mark T.Leary, and Michael R.Roberts, 2015, A century of capital structure: The leveraging of corporate America, Journal of Financial Economics, Volume 118, Issue 3, December 2015, Pages 658-68, https://doi.org/10.1016/

j.jfineco.2014.08.005

Justyna Franc-Da،browska , Magdalena Ma draSawicka and Magdalena Ulrichs, 2020, Economic Research-Ekonomska IstraZivanja, Vol. 33, No. 1, 1108-1129

Kasmir. Analisis Laporan Keuangan. Edisi Pertama, Cetakan Ketujuh. Jakarta: PT. Rajagrafindo Persada. Tahun 2014.

Malinić, D., Denčić-Mihajlov, K. and Ljubenović, E. 2013, “The determinants of capital structure in emerging capital markets: evidence from Serbia“, European Research Studies, vol. 16, № 2, pp. 98-119.

Mazhar, N.,\& Nasr, M. (2010). Determinants of Capital Structure Decisions: Case of Pakistani Government Owned and Private Firms. International Review of Business Research,6(1), 40-46.

Mazur, Kinga. (2007). The Determinants of Capital Structure Choice: Evidence from Polish Companies. International Advances in Eco- nomic Research. 13. 495-514. 10.1007/ s11294-007-9114-y.

Mehran, H. 1992, "Executive Incentives Plans, Corporate Control, and Capital Structure", Journal of Financial and Quantitative Analysis, 27, $539-560$.

Mei Qiu \& Bo La, 2010, Firm Characteristics as Determinants of Capital Structures in Australia, International Journal of the Economics of Business, Vol. 17, No. 3, 277-287

Michael Halling, Jin Yu Josef Zechner, 2016, Leverage dynamics over the business cycle, Journal of Financial Economics, Volume 122, Issue 1, October 2016, Pages 21-41, https://doi.org/10.1016/

j.jfineco.2016.07.001

Milton, H., \& Raviv, A. 1991. The theory of capital structure. Journal of Finance, 46(1), 297 -355 .

Modigliani, F., \& Miller, M. H. 1958. The cost of capital, corporation finance and the theory of investment. The American Economic Review, 261-297.

Modigliani, F., \& Miller, M. H. 1963. Corporate income taxes and the cost of capital: A correction. The American Economic Review, 433-443.

Mohammad, N. F., dan Suhadak. 2015. Pengaruh Kebijakan Dividen dan Pertumbuhan Perusahaan Terhadap Struktur Modal dan Profitabilitas (Studi Pada Sektor Mining yang Terdaftar di Bursa Efek Indonesia Periode 2011 -2013). Jurnal Administrasi Bisnis, 24 (1):110

Murray Z. Frank Vidhan K. Goyal, 2009, Capital Structure Decisions: Which Factors Are 
Reliably Important?, Financial Management, Vol. 38, Issue 1, Spring, 1-37

Muzzammil Hussain, Hassan Shahid and Muhammad Akmal, 2016, Effect of Profitability and Financial Leverage on Capita Structure in Pakistan Textile Firms, Arabian Journal of Business and Management Review, Vol. 6, Issue 4: 1-4

Myers, S. C. 1977. Determinants of corporate borrowing. Journal of Financial Economics, 5(2), 147-175. https:// doi.org/10.1016/0304-405X(77)90015-0

Myers, S. C. 1984. The capital structure puzzle. The Journal of Finance, 39(3), 574-592. https://doi.org/10.1111/j.15406261.1984.tb03646.x

Myers, S. C., \& Majluf, N. S. 1984. Corporate financing and investment decisions when firms have information that investors do not have. Journal of Financial Economics, 13 (2), 187-221.

Myers, S. C. 2001. Capital structure. Journal of Economic perspectives, 15(2), 81-102.

Narinder Pal Singh, Mahima Bagga, 2019, The Effect of Capital Structure on Profitability: An Empirical Panel Data Study, Jindal Journal of Business Research, Volume 8 Issue 1, June, 65-77

Naz, I., Shah, S. M. A., \& Kutan, A. M. 2017. Do managers of sharia-compliant firms have distinctive financial styles?. Journal of International Financial Markets, Institutions and Money, 46, 174-187.

Öztekin, Ö. 2015. Capital structure decisions around the world: which factors are reliably important?. Journal of Financial and Quantitative Analysis, 50(3), 301-323.
Pacific-Basin Finance Journal 7, 371-403.

Pepis, Scott \& de Jong, Pieter, 2019. "Effects of Shariah-compliant business practices on long-term financial performance," PacificBasin Finance Journal, Elsevier, vol. 53(C), pages 254-267

Quratulain Zafar, Winai Wongsurawat, David Camino, The determinants of leverage decisions: Evidence from Asian emerging markets, Cogent Economics \& Finance, Vol. 7, 2019 - Issue 1, 1-28

R. Angayarkanni, 2018, Measuring The Capital Structure, Profitability And Eva: With Reference To Selected Aviation Firms In India. IJRDO - Journal of Social Science and Humanities Research (ISSN: 2456-2971), 3(1), 103-111

Rafiq, I. Atiq (2008),“. The Determinants of Capital Structure of the Chemical Industry in Pakistan, The Lahore Journal of Economics, 139-158.

Rajan, R. G., \& Zingales, L. 2003. The great reversals: The politics of financial development in the twentieth century. Journal of Financial Economics, 69(1), 5-50. https:// doi.org/10.1016/S0304-405X(03)00125-9

Rathiranee Yogendrarajah, 2015, Impact of Capital Structure on Profitability - Evidence from selected Trading Companies in Colombo Stock Exchange, Sri Lanka, International Journal of Management and Social Sciences Vol. 03(issue 08), January: 469 479

Sahudin, Z., Ismail, Z., Sulaiman, S., Rahman, H. A., \& Jaafar, M. N. 2019. Capital Structure Determinants of Shariah-compliant Firms. 
Journal Of Emerging Economies and Islamic Research, 7(1), 65-75.

Scott, H. 1977. Bankruptcy, Secured Debt, and Optimal Capital Structure. The Journal of Finance 32(1): 1-19. Retrieved from http:// www.jstor.org/stable/ 2326898. Diakses tanggal 3 April 2014.

Serkan Akguc and Naseem Al Rahahleh, 2018, Shariah Compliance and Investment Behavior: Evidence from GCC Countries, Emerging Markets Finance and Trade, Emerging Markets Finance and Trade 54 (12), Spring, 2874-2896

Sheikh, N. and Qureshi, M. 2017. "Determinants of capital structure of Islamic and conventional commercial banks: Evidence from $\mathrm{Pa}$ kistan", International Journal of Islamic and Middle Eastern Finance and Management, Vol. 10 No. 1, pp. 24-41.

Sheikh, N. A., \& Wang, Z. 2011. Determinants of capital structure: An empirical study of firms in manufacturing industry of Pakistan. Managerial Finance, 37(2), 117-133. https://

doi.org/10.1108/03074351111103668

Stulz, R. 1990. Managerial discretion and optimal financing policies. Journal of Financial Economics, 26(1), 3e27.

Sukor, M. E. A., Halim, A. A., \& Bacha, O. I. 2018. The capital structure decisions of Shariah compliant and non-compliant firms: Evidence from Malaysia. 20th $M a-$ laysian Finance Association Conference 2018: Innovative Ecosystem for Financial Revolution.

Tang, C. H. H., \& Jang, S. S. 2007. Revisit to the determinants of capital structure: A com- parison between lodging firms and software firms. International Journal of Hospitality Management, 26(1), 175-187.

Titman, S., \& Wessels, R. 1988. The determinants of capital structure choice. The Journal of Finance, 43(1), 1-19. https:// doi.org/10.1111/j.15406261.1988.tb02585.x

Toy, N., Stonehill, A., Remmers, L. and Beekhuisen, T. 1974, “A comparative international study of growth, profitability, and risk as determinants of corporate debt ratios in the manufacturing sector", The Journal of Financial and Quantitative Analysis, vol. 9, № 5, pp. 875-886.

Tung Lam Dang, Hai Ly Ho, Chi Dzung Lam, Thanh Thao Tran \& Xuan Vinh Vo, 2019, Stock liquidity and capital structure: International evidence, Cogent Economics \& Finance, $7: 1,1-20$

Viviani, J. L. 2008. Capital structure determinants: an empirical study of French companies in the wine industry. International journal of wine business research.

Wald, J. K. 1999. How firm characteristics affect capital structure: an international comparison. Journal of Financial research, 22(2), 161-187.

Wiwattanakantang, Y., 1999. An empirical study on the determinants of the capital structure of Thai firms.

Yildirim, R., Masih, M., \& Bacha, O. I. 2018. Determinants of capital structure: evidence from Shari'ah compliant and non-compliant firms. Pacific-Basin Finance Journal, 51, 198-219. 
Zhiyao Chen, Jarrad Harford and Avraham Kamara, 2019, Operating Leverage, Profitability, and Capital Structure, Journal of Financial and Quantitative Analysis, Vol. 54, Issue 1, February , pp. 369-392 